\title{
NETRADICINIŲ PRIEMONIŲ TAIKYMO POVEIKIS METIMŲ TIKSLUMO RODIKLIŲ KAITAI
}

\author{
Rasa Kreivytė, Stanislovas Stonkus \\ Lietuvos kūno kultūros akademija, Kaunas, Lietuva
}

\begin{abstract}
Rasa Kreivytė. Sporto magistrè. Lietuvos kūno kultūros akademijos edukologijos mokslų doktorantė. Sportinių žaidimų katedros asistentė.
\end{abstract} Mokslinių tyrimų kryptis - metimų i krepši priklausomybė nuo jị lavinančiu programų.

\section{SANTRAUKA}

Paskutiniais metais metimu $\dot{j}$ krepš̌ tikslumas, pastovumas imtas nagrinèti ìvairiomis žaidimo situacijomis tiriant kamuolio išmetimo, jo skriejimo greiti ir laika, taikant ivairias pagalbines ir netradicines priemones, lemiančias metimu i krepši veiksmo, jo atskiru daliu (judesiu) pastovuma, tiksluma (Amberry, 1996; Stonkus, 2003; Palubinskas, 2004; Cooper, 2005; Fontanella, 2006; Wolf, 2006 ir kt.).

Susipažinus su metimu $\dot{i}$ krepši technikos, jos pastovumo, tikslumo priklausomybès tyrimais, suvokiant teorinę ir praktinę tokiu tyrimu ir ju išvadu reikšmę, aktuali moksliné problema: koki poveikį turi parengiamieji judesiai, taikant įvairias netradicines pagalbines priemones (pagalbinès rankos įtvara, specialu mokomaji kamuoli) krepšininkiu metimu $\mathrm{i}$ krepši pastovumui ir tikslumui.

Tyrimo tikslas - nustatyti bei įvertinti specialaus pagalbinès rankos įtvaro ir mokomojo kamuolio poveikị metimo $\dot{k}$ krepši tikslumo kaitai.

Tiriamaji kontingenta sudarè jaunosios (14-15 m.) krepšininkès $(n=36)$. Eksperimentinès grupés žaidèjos $(n=18)$ buvo suskirstytos i tris grupes: pirma meté baudos metimus su specialiu pagalbinès rankos itvaru, kuris imobilizuoja pagalbinés rankos judesí metant $i$ krepši $(n=6)$; antra grupé metè su specialiu mokomuoju kamuoliu $(n=6)$, trečia - mišri (naudojo specialy itvarq ir specialu kamuoli). Kontrolinès grupès žaidejos $(n=18)$ baudos metimus metè be specialiu pagalbiniu priemoniu. Tris kartus per savaite (eksperimentas truko 4 savaites) buvo metami baudos metimai $(n=100)$, žaidejjai pačiai pasiimant kamuoli po mesto baudos metimo. Buvo registruojamas tiksliu baudos metimu skaičius ir atlikimo laikas. Kiekvieno bandymo metu krepšininkè buvo vertinama pagal atlikto metimo rodiklius. Taikant specialias pagalbines metimo i krepši priemones (specialu pagalbinés rankos ïtvarq ir specialu mokomaji kamuoli) geriausi rezultatai buvo trečios eksperimentinès grupès, kurios tiriamosios baudos metimus metè su itvaru ir specialiu kamuoliu. Šios grupés tiksliu metimu $i$ krepši skaičius po eksperimento pagerëjo nuo 52,3 \pm 9,1 iki 79,0 \pm 9,8 (+26,7 tikslaus metimo). Grupe krepšininkiu, kurios metè metimus tik su specialiu mokomuoju kamuoliu, tiksliu baudos metimu skaičiı pagerino nuo 51,2 \pm 8,5 iki 70,8 \pm 8,6 $(+19,6)$. Grupè, kuri meté baudos metimus su specialiu nemetamosios rankos įtvaru, tiksliu metimu skaičiu pagerino nuo 52,2 \pm 9,5 iki 72,7 \pm 9,6 metimu (+20,5). Visu triju eksperimentiniu grupiu baudos metimu $\dot{k}$ krepš́ tikslumo rodikliai, lyginant su kontrolinès grupés rodikliais, po eksperimento pagerëjo statistiškai reikšmingai $(p<0,05)$, todèl netradiciniu pagalbiniu priemoniu taikymas ugdant ir ìtvirtinant šio technikos veiksmo iggüdžius yra veiksmingas.

Raktažodžiai: krepšinis, baudos metimai, specialus pagalbinès rankos ittvaras, specialus mokomasis kamuolys.

\section{IVADAS}

$\mathrm{M}$ etimai į krepši - baigiamieji puolimo veiksmai. Jeigu atliekant kitus technikos veiksmus galimos didesnès ar mažesnès paklaidos, tai metant kamuoli i krepši metimų tikslumas yra svarbiausia ir būtina sąlyga. Metimu i krepši tikslumas gerinamas pamažu, tobulinant judesių techniką ir lavinant metimo pajautimą. Metimo pajautimas - tai nuotolio tarp krepšio ir metančiojo bei iqdedamos jègos išmetant kamuoli i krepši ivertinimas (Carmenati, 1998; Stonkus, 2003).
Svarbiausio technikos veiksmo žaidžiant krepšini - metimu i krepši - veiksmingumo priklausomybė daugialypė: metimų tikslumą žaidžiant lemia tiek veiksmo biomechaniniai dydžiai (Miller, 2000; Fontanella, 2006), tiek judesių pastovumas (Amberry, 1996; Kladopoulos, McComas, 2001), tiek organizmo gebejjimas prisitaikyti prie įvairaus intensyvumo ir pobūdžio fizinių krūvių (Stonkus, 2003; Cooper, 2005), tiek žaidejju psichika (Wrisberg, Pein, 1992). 


\begin{tabular}{|c|c|c|c|}
\hline Rodiklis & Eksperimentinè & Kontrolinè & $\mathbf{p}$ \\
\hline Ūgis, m & $173,7 \pm 6,11$ & $170,9 \pm 5,00$ & $>0,05$ \\
\hline Kūno masè, kg & $61,9 \pm 6,69$ & $58,5 \pm 4,22$ & $>0,05$ \\
\hline Žaidimo patirtis, m. & $4,4 \pm 0,85$ & $4,7 \pm 0,57$ & $>0,05$ \\
\hline
\end{tabular}

1 pav. Specialios pagalbinès metimo i krepši technikos ir tikslumo tobulinimo priemonès
Pastaba. a - specialus pagalbinès rankos itvaras; b - specialus mokomasis kamuolys. a)

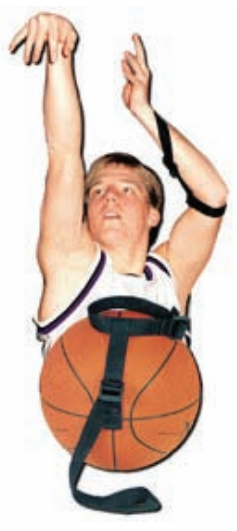

b)

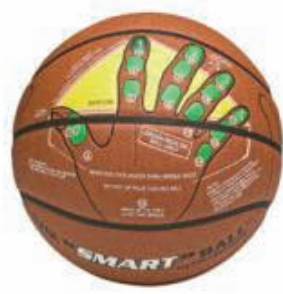

Todèl paskutiniais metais metimų $\mathfrak{i}$ krepši tikslumas, jo pastovumas imtas nagrinèti esant ivvairioms žaidimo situacijoms skirtingais aspektais: tiriant kamuolio išmetimo, jo skriejimo greiti ir laika, tikslumo gerinimą taikant įvairias pagalbines ir netradicines priemones, lemiančias metimų i krepši veiksmo, jo atskirų daliu (judesių) pastovumą, tikslumą (Palubinskas, 2004; Wolf, 2006).

Susipažinus su metimų i krepši technikos, jos pastovumo, tikslumo priklausomybès tyrimais, suvokiant teorinę ir praktinę tokių tyrimų ir jų išvadų reikšmę, aktuali tokia mokslinė problema: koki poveikị turi parengiamieji judesiai, taikant ivairias netradicines pagalbines priemones (specialų pagalbinès rankos įtvarą ir specialų mokomaji kamuolị) krepšininkių metimų i krepši pastovumui ir tikslumui.

Hipotezè. Taikant specialias pagalbines metimo i krepši priemones (kamuolius, ittvarus) pratybose turètu gerèti metimo i krepši judesiu pastovumas, kartu ir baudos metimų tikslumas.

Tyrimo tikslas - nustatyti ir ivertinti specialių priemonių poveikị metimo į krepši tikslumo kaitai.

Taikyti tokie mokslinio tyrimo metodai:

1. Ugdomasis eksperimentas.

Eksperimento esmé: ne mažiau kaip tris kartus per savaitę pratybų metu po pramankštos buvo metami baudos metimai $(n=100)$, žaidejjai pačiai pasiimant kamuoli po baudos metimo. Buvo registruojamas metimų $\mathfrak{i}$ krepši tikslumas ir atlikimo laikas. Eksperimentas truko vieną mènesi.
Pirmos eksperimentinès grupès žaidejjoms $(\mathrm{n}=6)$ metant baudos metimus buvo naudojamas specialus pagalbinès rankos įtvaras (Wolf, 2006), kuris imobilizuoja pagalbinès rankos judesį metant kamuoli i krepši (jei žaidejja dešiniarankè — ittveriama kairé, jei kairiarankè — dešinè). Antros grupès žaidèjos $(n=6)$ metė 100 baudos metimu su specialiais mokomaisiais kamuoliais (Palubinskas, 2004). Trečios grupès žaidèjos $(n=6)$ baudos metimus mete ir su specialiais įtvarais, ir su kamuoliais. Kontrolinès grupès krepšininkès $(n=18)$ baudos metimus metė i krepši be specialiu pagalbiniu priemonių (1 pav.).

\section{Testavimas.}

Eksperimento pradžioje ir pabaigoje kiekviena žaidèja metė po 100 baudos metimų iš eilès pati pasiimdama kamuoli. Buvo registruojamas tikslių ir netikslių metimu i krepši skaičius ir atlikimo laikas. Kiekvieno bandymo metu krepšininkè buvo vertinama pagal atlikto metimo rodiklius. Sutartiniais ženklais specialiame protokole buvo registruojami tikslūs metimai: įmesti atšokus kamuoliui nuo skydo, palietus lanką (priekinę lanko dali, dešinę, kairę), nepalietus lanko. Netikslūs: kamuoliui atšokus nuo skydo, nuo lanko (priekinès lanko dalies, dešinès, kairès).

Tiriamosios. Pedagoginio eksperimento metu buvo tiriamos trisdešimt šešios $(\mathrm{n}=36) 14-15$ metų adekvataus sportinio meistriškumo jaunosios krepšininkès. Jos buvo suskirstytos i dvi grupes: eksperimentinę $(n=18)$ ir kontrolinę $(n=18)$. Eksperimentinès grupès krepšininkès atsitiktinès atrankos būdu suskirstytos dar $\mathfrak{i}$ tris grupes: pirmą $(n=6)$, antrą $(n=6)$ ir trečią $(n=6)$. Prieš 
eksperimentą nustatyti tiriamujų kūno sudejjimo ir žaidimo patirties rodikliai. Eksperimentinès ir kontrolinės grupių krepšininkių rodikliai iš esmès nesiskyrè (1 lent.).

Statistine analizé. Apskaičiuoti gautų rodikliu aritmetiniai vidurkiai, standartiniai nuokrypiai. Dèl nedidelio rungtynių skaičiaus buvo taikytas neparametrinis kriterijus priklausomoms imtims palyginti - Wilcoxon ženklų kriterijus, nepriklausomoms - Mann-Whitney-Wilcoxon rangu sumų kriterijus (Pukènas, 2005). Reikšmingumo lygmuo - 0,05. Duomenų analizè atlikta naudojant SPSS for Windows programą.

\section{REZULTATAI}

Jaunujų krepšininkių baudos metimų testo (100 baudos metimu) prieš eksperimentą vidutinis tikslumo rodiklis buvo: pirmos eksperimentinès grupès, kurios krepšininkės metė baudos metimus su pagalbinès rankos ittvaru $-52,2 \pm 7,5$ tikslių metimu, antros (su specialiais kamuoliais) $51,2 \pm 8,5$, trečios grupès (su įtvarais ir specialiais kamuoliais) - 52,3 \pm 7,1 tikslių metimų.
Visos trys eksperimentinès grupės baudos metimų testui atlikti sugaišo atitinkamai $12,02 \pm 0,8,11,44 \pm 1,0$ ir $11,31 \pm 1,3$ min. Kontrolinès grupès baudos metimų testo vidutinis rodiklis $-54,4 \pm 9,8$ tikslūs metimai, testo atlikimo laikas $-13,00 \pm 1,1 \mathrm{~min}$.

Didelio baudos metimų vidutinių rodiklių skirtumo tarp trijų eksperimentinių ir kontrolinès grupés I testavimo metu nebuvo $(p>0,05)$ (2 lent., 2 pav.).

Eksperimentinių grupių vidutiniai baudos metimų rodikliai pirmą eksperimento savaitę nedaug pagerèjo: pirmos grupès (su ittvarais) $-57,7 \pm 7,2$ tikslių baudos metimų iš 100 mestu, antros (su kamuoliais) - 58,5 $\pm 7,7$, trečios (su ittvarais ir kamuoliais) $-58,5 \pm 7,4$.

Jau po antros eksperimento savaitès šiu grupių baudos metimų vidutiniai rodikliai smarkiai pagerèjo, lyginant su gautais prieš eksperimentą: pirmos grupès - 64,2 \pm 6,7 tikslių baudos metimu iš 100 mestu, antros - 63,7 \pm 8 ,2, trečios $-70,3 \pm 8,6(\mathrm{p}<0,05)$. Kur kas geresniu baudos metimų vidutinių rodiklių pasieke visos trys eksperimentinès grupès trečią (pirmos grupès $-68,7 \pm 7,3$ tikslių baudos metimu iš 100

\begin{tabular}{|c|c|c|c|c|c|c|c|c|c|c|}
\hline \multirow{3}{*}{\multicolumn{2}{|c|}{$\begin{array}{c}\text { Baudos metimai } \\
\text { (100 metimų) }\end{array}$}} & \multirow[b]{2}{*}{$\begin{array}{c}\text { I } \\
\text { testavimas }\end{array}$} & \multirow[b]{2}{*}{$\begin{array}{c}\text { Laikas, } \\
\min \end{array}$} & \multicolumn{4}{|c|}{ Eksperimentas } & \multirow[b]{2}{*}{$\begin{array}{c}\text { II } \\
\text { testavimas }\end{array}$} & \multirow[b]{2}{*}{$\begin{array}{c}\text { Laikas, } \\
\text { min }\end{array}$} & \multirow{3}{*}{$\begin{array}{l}2 \text { lentelè. Jaunųjų krep- } \\
\text { šininkių baudos metimų } \\
\text { rodikliai }\end{array}$} \\
\hline & & & & $\begin{array}{c}\text { I } \\
\text { savaite் }\end{array}$ & $\begin{array}{c}\text { II } \\
\text { savaitė }\end{array}$ & $\begin{array}{c}\text { III } \\
\text { savaitè }\end{array}$ & \begin{tabular}{|c|} 
IV \\
savaitè
\end{tabular} & & & \\
\hline & & \multicolumn{8}{|c|}{$(\bar{X} \pm S)$} & \\
\hline \multirow{3}{*}{$\begin{array}{l}\text { Eksperi- } \\
\text { mentinè } \\
\text { grupé }\end{array}$} & Su ịtvarais & $\begin{array}{l}52,2 \\
\pm 7,5 \\
\end{array}$ & $\begin{array}{l}12,02 \\
\pm 0,8 \\
\end{array}$ & $\begin{array}{l}57,7 \\
\pm 7,2 \\
\end{array}$ & $\begin{array}{l}64,2 * \\
\pm 6,7\end{array}$ & $\begin{array}{l}68,7 * \\
\pm 7,3\end{array}$ & $\begin{array}{l}72,0 * \\
\pm 7,5\end{array}$ & $\begin{array}{l}72,7^{*} \\
\pm 7,6\end{array}$ & $\begin{array}{l}12,47 \\
\pm 0,8\end{array}$ & \multirow{4}{*}{$\begin{array}{l}\text { Pastaba. } *-p<0,05 \\
\text { skirtumo reikšmingumo } \\
\text { lygmuo, lyginant su pirmo } \\
\text { testavimo vid. reikšme; } \\
* *-p<0,05 \text { skirtumo } \\
\text { reikšmingumo lygmuo, ly- } \\
\text { ginant su eksperimentinės } \\
\text { grupės antro testavimo vid. } \\
\text { reikšme. }\end{array}$} \\
\hline & Su kamuoliais & $\begin{array}{l}51,2 \\
\pm 8,5 \\
\end{array}$ & $\begin{array}{l}11,44 \\
\pm 1,0 \\
\end{array}$ & $\begin{array}{l}58,5 \\
\pm 7,7 \\
\end{array}$ & $\begin{array}{l}63,7 * \\
\pm 8,2 \\
\end{array}$ & $\begin{array}{l}66,8^{*} \\
\pm 8,5\end{array}$ & $\begin{array}{l}70,0 * \\
\pm 7,8 \\
\end{array}$ & $\begin{array}{l}70,8^{*} \\
\pm 7,6\end{array}$ & $\begin{array}{l}12,08 \\
\pm 1,6 \\
\end{array}$ & \\
\hline & $\begin{array}{l}\text { Su ittvarais ir } \\
\text { kamuoliais }\end{array}$ & $\begin{array}{l}52,3 \\
\pm 7,1 \\
\end{array}$ & $\begin{array}{l}11,31 \\
\pm 1,3 \\
\end{array}$ & $\begin{array}{l}58,5 \\
\pm 7,4 \\
\end{array}$ & $\begin{array}{l}70,3^{*} \\
\pm 8,6\end{array}$ & $\begin{array}{l}75,5^{*} \\
\pm 7,4\end{array}$ & $\begin{array}{l}78,3^{*} \\
\pm 7,4\end{array}$ & $\begin{array}{l}79,0^{*} \\
\pm 7,8\end{array}$ & $\begin{array}{l}12,10 \\
\pm 1,9 \\
\end{array}$ & \\
\hline \multicolumn{2}{|c|}{ Kontrolinė grupė } & $\begin{array}{l}54,4 \\
\pm 9,8 \\
\end{array}$ & $\begin{array}{l}13,00 \\
\pm 1,1 \\
\end{array}$ & - & - & - & - & $\begin{array}{l}56,3 * * \\
\pm 8,8\end{array}$ & $\begin{array}{l}12,18 \\
\pm 1,4\end{array}$ & \\
\hline
\end{tabular}

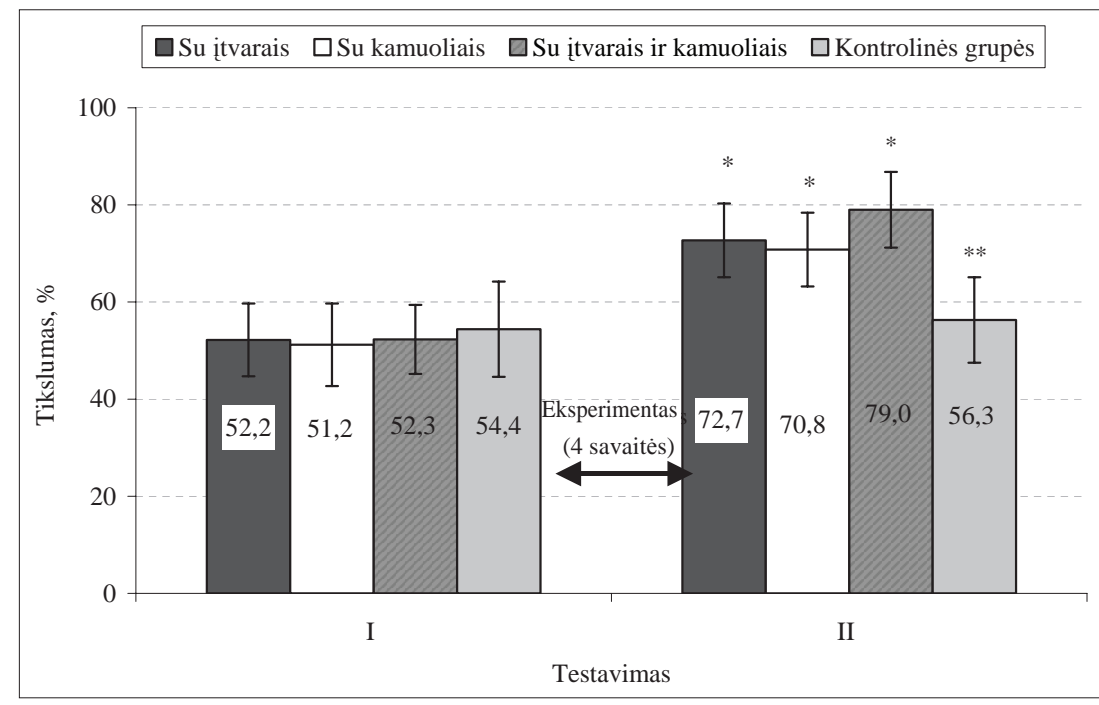

2 pav. Jaunųjų krepšininkių baudos metimų tikslumas prieš eksperimentą ir po jo

Pastaba. * $-\mathrm{p}<0,05$ skirtumo reikšmingumo lygmuo, lyginant su pirmo testavimo vid. reikšme; $* *-\mathrm{p}<0,05$ skirtumo reikšmingumo lygmuo, lyginant su eksperimentinès grupès antro testavimo vid. reikšme. 
3 pav. Eksperimentinių grupiụ baudos metimų kaitos rodikliai eksperimento metu

Pastaba. * - p $<0,05$ skirtumo reikšmingumo lygmuo, lyginant su pirmo testavimo vid. reikšme.

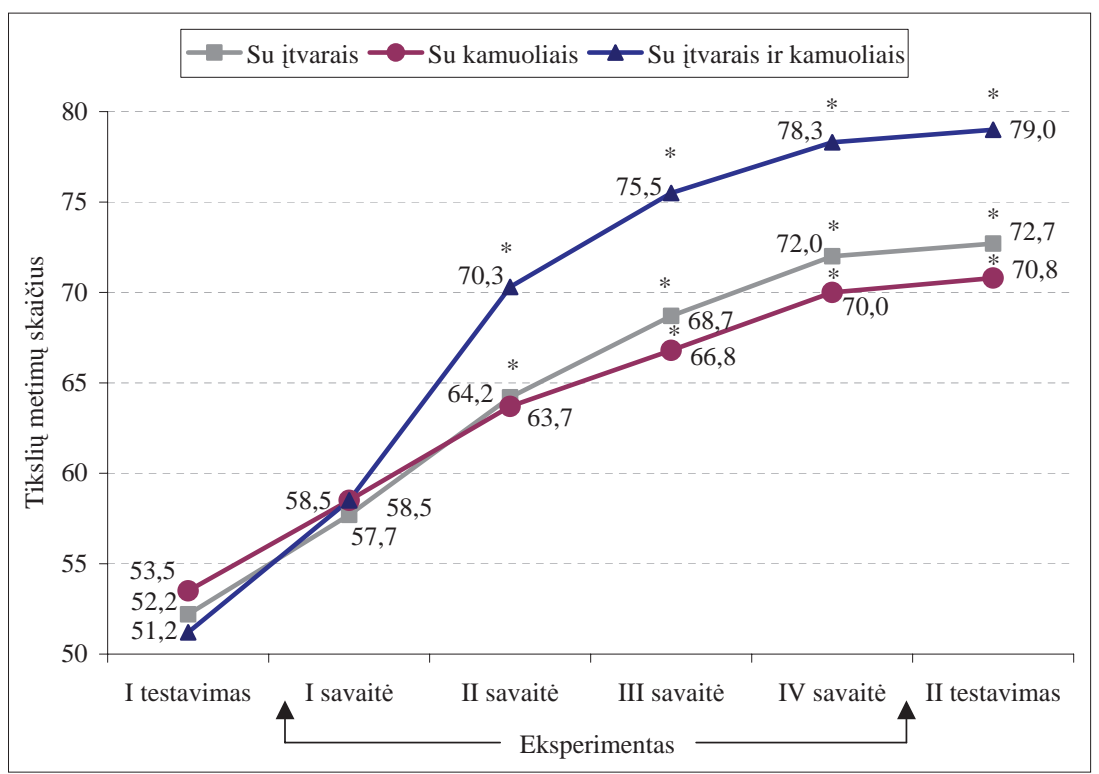

mestu, antros $-66,8 \pm 8,5$, trečios $-75,5 \pm 7,7$ ) $(\mathrm{p}<0,05)$ ir ketvirtą eksperimento savaitę (pirmos grupès - 72,0 \pm 7,5 tikslių baudos metimu iš 100 mestu, antros - 70,0 $\pm 7,8$, trečios $78,3 \pm 7,4)(\mathrm{p}<0,05)$.

Po mėnesi trukusio eksperimento atlikus antrą baudos metimų testavimą nustatyta, kad kontrolinès grupès imestų baudos metimų skaičius pagerèjo $+1,9$ metimo, tačiau ryškaus vidutinių rodikliu skirtumo nebuvo $(p>0,05)$. Šių metimų testo atlikimo greitis vidutiniškai sumažèjo $0,42 \mathrm{~min}$.

Eksperimentiniu grupių antro baudos metimu testavimo vidutiniai rodikliai smarkiai pageréjo, lyginant su pirmu testavimu $(\mathrm{p}<0,05)$.

Taikant specialias pagalbines metimo i krepši priemones (specialu pagalbinės rankos įtvarą ir specialu mokomaji kamuoli) geriausių rezultatu pasiekè trečia eksperimentinè grupè, kuri baudos metimus metė su įtvaru ir specialiu kamuoliu. Šios grupès tikslių metimų i krepši skaičius pagerejjo nuo 52,3 \pm 9,1 iki 79,0 \pm 9,8 (+26,7 tikslaus metimo) (3 pav.).

Grupè krepšininkių, kurios metė metimus tik su specialiu mokomuoju kamuoliu, tiksliu baudos metimų skaičių pagerino nuo 51,2 \pm 8,5 iki $70,8 \pm 8,6(+19,6)$. Grupé, kuri baudos metimus metè su specialiu nemetamosios rankos itvaru, tikslių metimų skaičių pagerino nuo 52,2 \pm 9,5 iki $72,7 \pm 9,6(+20,5)$. Ryškaus tikslių baudos metimuc vidutinių rodiklių skirtumo padidejjimo tarp trijų eksperimentiniu grupių nebuvo ( $p>0,05)$.

Dèl taikomu specialių metimo i̇ krepši pagalbiniu priemonių laikas, sugaištas testui atlikti, padidejjo visų trijų eksperimentinių grupių (2 lent., 3 pav.).
Baudos metimų judesių pastovumą apibūdina tikslių ir netikslių metimų rodikliai, jų kaita, taip pat situacijos, kai kamuolys ikkrenta arba neikrenta i krepšit.

Tiksliu metimų situacijos gali būti: kamuolys ikrito ị krepši neliesdamas skydo ir lanko (labai tikslus), atšokęs nuo skydo, atšokęs nuo priekinès, kairès ar dešinès lanko dalies.

Labai tikslių baudos metimų (kamuolys nelietè nei lanko, nei skydo) pirmos eksperimentinès grupès (naudojosi pagalbinès rankos ittvaru) žaidejjų prieš eksperimentą siekẻ $35 \%$ visų ikritusių i krepši baudos metimu, po eksperimento labai tikslūs metimai sudarè 64\%, antros (naudojosi specialiu kamuoliu) - 38 ir $63 \%$ ir trečios grupès (naudojosi itvaru ir kamuoliu) - 34 ir 69\% (4 pav.).

Ikritusių baudos metimų skaičius, kai kamuolys lietė priekinę lanko dali, pirmos eksperimentinès grupès žaidėjų prieš eksperimentą siekè $14 \%$ visu ikritusių i krepši baudos metimu, po eksperimento dali, sudarè $13 \%$, antros - 15 ir $13 \%$ ir trečios grupès -18 ir $13 \%$ metimų.

Ikritę baudos metimai, kai kamuolys lietė galinę lanko dali arba skyda, pirmos eksperimentinès grupès žaidejju prieš eksperimentą sudarè $16 \%$ visu ikritusių i krepši baudos metimu, po eksperimento baudos metimai, kai kamuolys lietė galinę lanko dali arba skyda, sumažèjo iki $9 \%$, antros - 15 iki $12 \%$ ir trečios grupès - 16 iki $9 \%$ metimų.

İkritusių baudos metimų, kai kamuolys lietė dešinę ar kairę lanko dalis, pirmos eksperimentinès grupès žaidėju prieš eksperimentą sudarè atitinkamai 20 ir 15\% visų ikkritusių i krepši baudos baudos metimai, kai kamuolys lietė priekinę lanko 

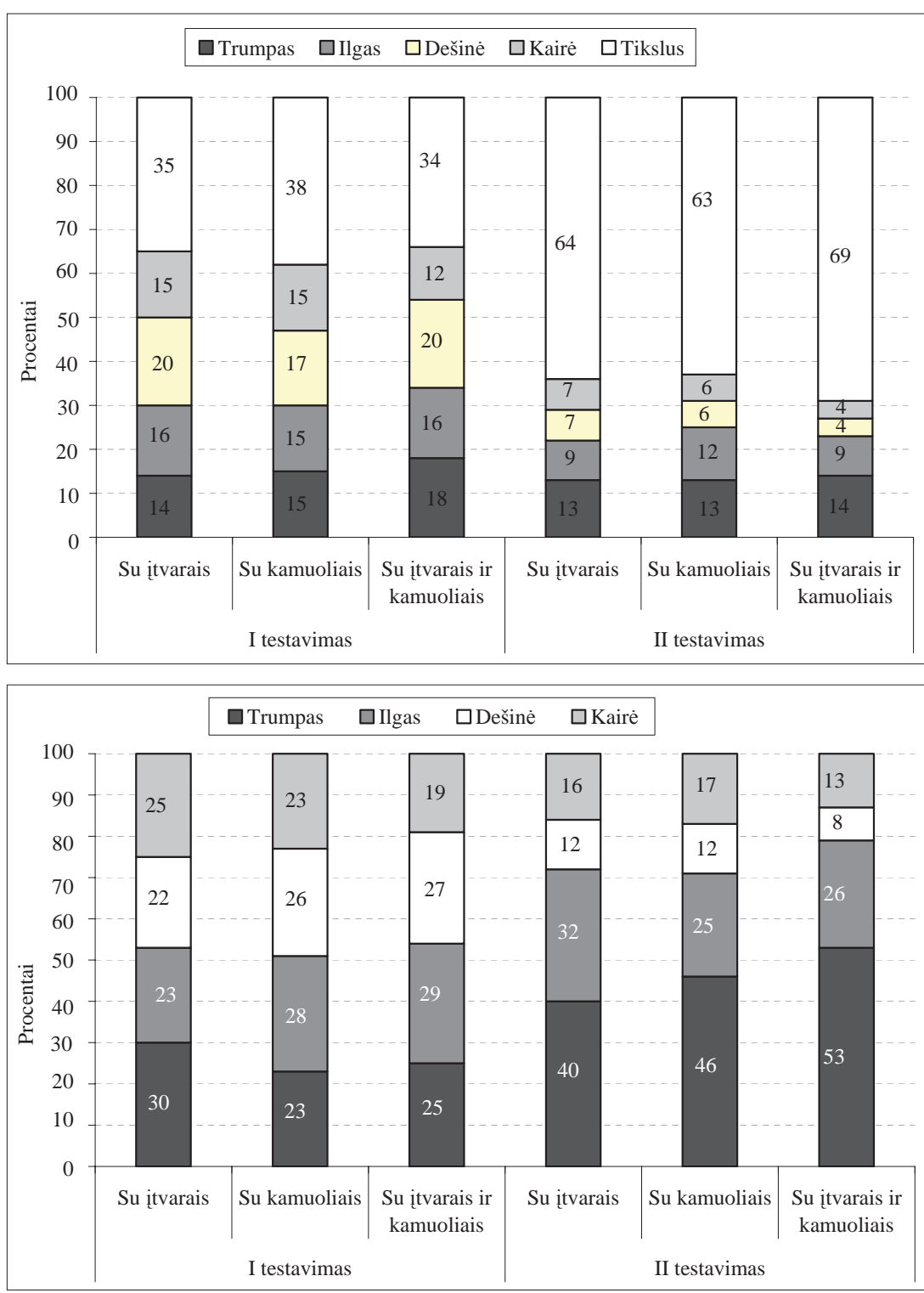

4 pav. Eksperimentinių grupių įmestų baudos metimų situaciniai rodikliai
5 pav. Eksperimentinių grupių pramestų baudos metimų situaciniai rodikliai metimų. Po eksperimento baudos metimai, kai kamuolys lietė dešine ir kaire lanko dali, sudarè tik po $9 \%$, antros -15 ir $17 \%$, po eksperimento sumažèjo iki $6 \%$ ir trečios grupès - 20 ir $12 \%$ metimu sumažèjo iki 4\% (4 pav.).

Pirmos eksperimentinès grupès pramestų baudos metimų rodikliai I testavimo metu tokie: 30\% metimu, kai kamuolys atšoko nuo lanko priekinès dalies, 23\% - kai atšoko nuo galinès lanko ar skydo dalies, 22\% netikslių metimu, kai kamuolys atšoko nuo dešinès lanko pusès ir 25\% - nuo kairès. Panašiai netikslių baudos metimų rodikliai pasiskirstė antroje ir trečioje eksperimentinèje grupèje.

Po eksperimento visų trijų eksperimentinių grupių pramestų baudos metimų situaciniai rodikliai tokie: dažniausiai pramesti baudos metimai atšoko nuo priekinès lanko dalies, mažiausiai nuo dešinès ar kairès (5 pav.).

\section{REZULTATŲ APTARIMAS}

Judesių mokymo, tobulinimo ir valdymo teorijoje vyrauja nuomonè, kad judesių igūdžių formavimo, jų ittvirtinimo stadijoje tikslingiau taikyti pastovius, nekintamomis sąlygomis atliekamus fizinius pratimus (Henry, 1960; Adams, 1987; Schmidt, Wrisberg, 2007), nes tokiomis sąlygomis igyti judesiu, veiksmu igūdžiai yra patvaresni, patys judesiai, veiksmai pastovesni, tikslesni (Fitts, Posner, 1967; Anderson, 1995; Rogers et al., 1997).

Viena iš sąlygu, garantuojančių baudos metimo igūdžiu formavimo pastovumą, yra pagalbinès priemonès, fiksuojančios reikiamas metančiosios ir pagalbinès rankos padètis (Amberry, 1996; Palubinskas, 2004; Wolf, 2006 ir kt.).

Pirmos eksperimentinès grupės (fiksuojant pagalbinę ranką) baudos metimų vidutiniai rodikliai po eksperimento (72,7 karto) smarkiai pagerejjo 
$(+20,5$ karto) $(\mathrm{p}<0,05)$. Taip pat pakito ir tiksliu šios eksperimentinès grupès žaidèjų situaciniai rodikliai: padaugejjo labai tikslių metimų skaičius (+29\%), sumažèjo metimų, kurie atsimušè į dešinę ar kairę lanko dali (7\%).

Eksperimentinès grupès baudos metimų tikslumo kaitos rodikliai patvirtino kitu autorių (Amberry, 1996; Wolf, 2006) išvadas, kad pagalbinès rankos pastovi padettis ir judesiai metant baudos metimus turi dideli poveikị metimo ị krepši veiksmų pastovumui, tikslumui.

Antros eksperimentinès grupès (su specialiu mokomuoju kamuoliu) baudos metimų i krepši vidutiniai tikslumo rodikliai po eksperimento $(70,8$ karto) taip pat labai pagerejo (+19,6 karto). Tai patvirtina šio testo vidutinių rodiklių skirtumo statistini patikimumą $(\mathrm{p}<0,05)$. Situaciniai šios grupès baudos metimų tikslumo rodikliai kito panašiai kaip ir pirmos eksperimentinès grupès: padidejo labai tikslių metimų skaičius (25\%), sumažèjo, kaip ir pirmos grupès, metimu, atsimušusiu i dešinę ar kairę lanko dali, skaičius (6\%).

Naudotas specialus kamuolys, metimų i krepši metu fiksuojant tikslią metamosios rankos pirštu padèti, leido veiksmingai suformuoti ir ittvirtinti pastovius tos rankos ir pirštu judesius išmetant kamuoli (kamuolio atsiskyrimą nuo rankos) (Palubinskas, 2004; Cooper, 2005).

Eksperimento duomenys leidžia teigti, kad specialaus kamuolio naudojimas per pratybas — veiksminga priemonė lavinant tirto amžiaus krepšininkių baudos metimo judesių, veiksmų tikslumą.

Trečios eksperimentinès grupès (su įtvaru ir specialiu kamuoliu) baudos metimu i krepši vidutiniai tikslumo rodikliai po eksperimento $(79,0$ karto) taip pat smarkiai pagerejo (+26,7 karto) $(\mathrm{p}<0,05)$. Situaciniai šios grupès baudos metimu vidutiniai tikslumo rodikliai kito panašiai kaip pirmos ir antros eksperimentinių grupių: padidèjo labai tikslių metimų skaičius (35\%), sumažèjo metimu̧ kurie atsimušè i dešinę ar kairę lanko dali, skaičius (4\%).

Analizuojant atskiru eksperimentinès grupès žaidèjų baudos metimų vidutinius tikslumo kaitos rodiklius, esminių skirtumų tarp jų nepastebėta ( $p>0,05)$.

Tirtų žaidejjų baudos metimų tikslumo rodikliu kaita, taikant netradicines pagalbines priemones, iš esmès atitinka kitų autorių pateiktą tų rodiklių kaitą (Amberry, 1996; Palubinskas, 2004; Wolf, 2006 ir kt.).

\section{IŠVADOS}

1. Visų trijų eksperimentinių grupių baudos metimų i krepši vidutiniai tikslumo rodikliai, lyginant su kontrolinės grupės rodikliais po eksperimento, pagerèjo statistiškai reikšmingai ( $<<0,05)$. Metimų i krepši tikslumas pagerèjo: 1 grupès - 20,7\%, 2-os - 19,4\%, 3-ios $26,3 \%$, todèl netradicinių pagalbinių priemonių taikymas formuojant ir itvirtinant šio technikos veiksmo igūdžius yra veiksmingas.

2. Specialaus pagalbinès rankos itvaro taikymas kartu su specialiu mokomuoju kamuoliu labiausiai paveikè krepšininkių baudos metimų tikslumą, tačiau didelio vidutinių rodiklių skirtumo tarp šių pagalbinių metimo ị krepši priemonių naudojimo nebuvo $(\mathrm{p}>0,05)$.

3. Netradicinių metimo i krepši priemonių taikymas turèjo reikšmès ir metimų situaciniams rodikliams: padaugejo labai tikslių metimu (išaugo 35\%), sumažèjo metimu, kurie ịkrito i krepši atsimušę nuo dešinès (16\%) ar kairès (9\%) lanko dalies.

\section{LITERATŪRA}

Adams, J. A. (1987). Historical review and appraisal of research on the learning, retention, and transfer of human motor skills. Psychological Bulletin, 101, 41-74.

Amberry, T. (1996). Free throw. Seven Steps to Success at the Free-throw Line. New York: Harper CollinsPublishers.

Anderson, J. R. (1995). Learning and Memory: An Integrative Approach. New York: Wiley.

Carmenati, R. (1998). Educating to Basketball. Roma: WBAC.

Cooper, K. (2005). Stunting from the free-throw line. Coach and Athletic Director, 75, 1, 36 (2).

Fitts, P. M., Posner, M. I. (1967). Human performance.
Pacific Grove, CA: Brookes / Cole.

Fontanella, J. J. (2006). The Physics of Basketball. Johns Hopkins University Press.

Henry, F. M. (1960). Increased response latency for complicated movements and a "memory-drum" theory of neuromotor reaction. Research Quarterly, 31, 448-458.

Kladopoulos, C. N., McComas, J. J. (2001). The effects of forms training on foul-shooting performance in members of a women's college basketball team. Journal of Applied Behavior Analysis, 34, 329-332.

Miller, S. (2000). Variability in basketball shooting: practical implications. International Research in Sports Biomechanics, 27-34. 
Palubinskas, E. (2004). The jump shot. FIBA Assist Magazine, 7, 6-11.

Rogers, W. A., Maurer, T. J., Salas, E., Fisk, A. D. (1997). Training design, cognitive theory, and automaticity: principles and a methodology. In J. K. Ford (Ed.), Improving Training Effectiveness in Work Organizations (pp. 19-44). Mahwah, NJ: Erlbaum.

Schmidt, R. A., Wrisberg, C. A. (2007). Motor Learning and Performance: A Situation-based Learning Approach. Human Kinetics Publishers.
Stonkus, S. (2003). Krepšinis: istorija, teorija, didaktika. Kaunas: LKKA.

Wolf, J. (2006). Five Star All-American Workouts. Six Structured Practice Routines Proven To Develop Outstanding Accuracy, Form \& Confidence. Star shooter Company. New Richmond, WI.

Wrisberg, C. A., Pein, R. L. (1992). The preshot interval and free throw shooting accuracy: An exploratory investigation. The Sport Psychologist, 6, 14-23.

\title{
THE EFFECT OF NON-TRADITIONAL AIDS ON THE CHANGE IN FREE THROW ACCURACY INDICES
}

\author{
Rasa Kreivytė, Stanislovas Stonkus \\ Lithuanian Academy of Physical Education, Kaunas, Lithuania
}

\begin{abstract}
Basketball throws are fundamental and final actions in the offence. When in the case of performance of any other technical actions, certain more or less significant errors are allowable, to play a perfect game, basketball shooting accuracy is the condition of the utmost importance and necessity. The basketball shooting accuracy is improving gradually when motor behaviour technique is being developed and a "feel of basketball shooting" mastered. The "feel of basketball shooting" means summing up the basket-shooter distance and the force being applied during the shooting action.

When special aids for basketball shooting (special balls, fastening devices) are applied during practical training sessions, the consistency of basketball shooting motor behaviour should improve, and, consequently, the accuracy of free throw performance should improve as well.

The aim of the research has to establish and evaluate the effect of special aids on the change in basketball shooting accuracy.

Thirty six girls basketball players aged $14-15$ years $(n=36)$ of adequate level of sports performance participated in the experiment. They were divided into two groups: the experimental $(n=18)$ one and the control $(n=18)$ one.

After performing the experiment, having carried out the 2 tests of free throws, it has been established that the number of scoring free throws made by the control group has improved by +1.9 throws, however there has been no significant difference in the indices $(p>0.05)$. The free throw performance results during the 2nd testing improved markedly in comparison to those of the 1st testing $(\mathrm{p}<0.05)$. When applying special aids for basketball shooting (a special fastening device for a non-shooting hand and a special training ball), the best result has been demonstrated by the third experimental group that executed its free throws using both the fastening device and the special ball. The number of scoring shots made by this group has improved from $52.3 \pm 9.1$ to $79.0 \pm 9.8$ (+26.7 scoring throws).

The free throw accuracy indices of the three experimental groups in comparison with the control group indices have improved statistically significantly after performing the experiment, therefore, application of non-traditional aids to the formation and mastering the skills of this technical action appears to be effective.
\end{abstract}

Keywords: basketball, free throw, shooting strap, special training ball.

Gauta 2009 m. sausio 27 d.

Received on January 27, 2009

Priimta 2009 m. kovo 5 d.

Accepted on March 5, 2009
Rasa Kreivytė

Lietuvos kūno kultūros akademija

(Lithuanian Academy of Physical Education)

Sporto g. 6, LT-44221 Kaunas

Lietuva (Lithuania)

Tel +370 37302653

E-mail kreivyte@centras.lt 